\title{
Effect of Mindfulness Based Sport Psychology Counseling on Injured Junior Baseball Players in Rehabilitation Process-Case Study
}

\author{
Yook Young Sook ${ }^{1^{*}}$
}

'Sungshin Women's University

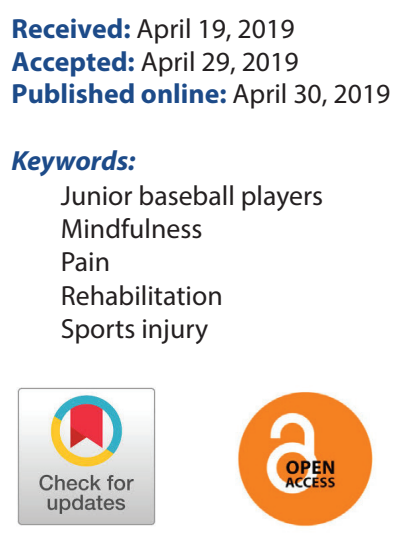

Received: April 19, 2019

Accepted: April 29, 2019

Published online: April 30, 2019

\section{Junior baseball players}

Mindfulness

Rehabilitation

Sports injury

\section{ABSTRACT}

OBJECTIVES Athletes and other stakeholders tend to focus on their physical aspects of rehabilitation although psychological factors may contribute to the success of return to sports. Therefore, the purpose of this case study was to apply the mindfulness based psychological skills training to injured junior baseball players during the rehabilitation process and examine the effect of the program.

METHODS The 8 sessions of the mindfulness based psychological skills training were conducted for 4 participants and K-PCS, K-CAMS-R, Perceived Performance Level, TOPS, PANAS, and CSAI-2 were implemented and analyzed.

RESULTS As a result, all of the variables significantly varied in a positive way after the intervention and additionally qualitative results, such as mindfulness and imagery, aided the quantitative result.

CONCLUSIONS Such positive effects of the intervention reinforced the importance of the role of psychological rehabilitation for injured athletes, and implication of this study was discussed.

( T) The Asian Society of Kinesiology and the Korean Academy of Kinesiology
서론

최근 해외 선행연구에 따르면 지난 1년간 축구, 아 이스하키, 농구, 크로스컨트리 스키, 피겨스케이팅, 체 조 그리고 육상 등에 참여하는 남•녀 청소년 선수들 중 $50.4 \%$ 가 스포츠와 관련된 부상을 경험한 것으로 보고 되고 있다[1]. 고도의 의학적 지식과 기술의 도움으로 대부분의 부상선수들은 부상 이전의 건강과 수행 수준 혹은 그 이상으로 완전히 회복 할 수 있는 가능성을 가 지고 있다. 하지만 많은 선수들이 부상 이전의 수준으로 회복하는데 있어 실패를 경험하고, 이러한 실패는 종종 심리적 요인들이 원인일 수 있다[2].

이는 심리적 요인들이 부상 발생에 영향을 미칠 수 있

*Correspondence: Yook YoungSook, Department of Exercise Rehabilitation Welfare, Sungshin Women's University, 2, Bomun-Ro 34Da-Gil, Seongbuk-Gu, Seoul, Korea Tel: +02-920-7571; E-mail: yookys@sungshin.ac.kr
고 또한 선수들이 부상에 성공적으로 대처하고 나아가 재활의 성공에도 영향을 미칠 수 있기 때문이다.[3-6]. 또한 여러 연구들을 통해 스포츠 손상과 자신감 감소, 개인 정체성 상실, 불안, 우울, 고립감 등 사이의 연결고 리가 발견되어 왔다[8-10].

운동선수들의 부상은 신체적인 반응 뿐만 아니라 인 지적, 정서적, 행동적 반응을 야기하기 때문에 신체적인 재활 뿐만 아니라 인지, 정서, 행동 반응을 조절하는 심 리적 접근을 병행할 필요가 있다[11]. 하지만 여러 가 지 이유에서 운동선수들은 신체적 재활에 초점을 두고 신체적 회복에만 집중하는 경향이 있다. 따라서 부상이 나 재활과정 중 발생한 심리적 문제를 해결하지 못한 채 현장에 복귀하게 되는 경우가 종종 있다.

운동선수의 재활과정에서 통증, 두려움, 과실평가는 재활 실패를 야기할 수 있는 요인으로 알려져 있다[12]. 
본 연구에서는 특히 부상선수들의 통증 경험과 이를 중 재하는 방안 및 심리기술 향상 대해 초점을 두고 진행되 었다. 통증은 조직의 직접적 혹은 잠재적 손상으로 인한 정서적, 감각적 경험으로 정의된다[13]. 통증을 느끼는 감각이나 원인 자체를 제거할 수는 없으나 통증을 어떻 게 해석하고 관리할 것인가는 재활중인 선수들에게 중 요한 일이다. 통증은 선수들에게 부상 당시 상황을 상 기시키고 재 부상에 대한 두려움(fear of re-injury)을 야기하여 재활에 전념하지 못하게 할 수 있기 때문이 다. 재활선수들의 정서상태 변화에 대한 연구에서는 부 상당한 선수들이 부상 직후 부정적인 정서가 상승하고 재활기간 중 점차적으로 감소한 후 재활완료 시점에 다 시 부정적인 정서를 보이는 U자형 진행 가설을 검증하 였다 $[14,15]$. 이렇게 부상 및 재활 중인 선수는 다양한 이유에서 현장복귀 이전까지 부정적 정서를 관리할 필 요가 있으며, 부정적 정서경험은 통증과 관련이 있기 때 문에 관심을 가질 필요가 있다[16].

이처럼 운동선수의 재활과정 중 정서, 인지, 행동 반 응에 영향을 미치는 통증이 부정적으로 통제되지 않도 록 하기 위해 본 연구에서는 마음챙김을 적용하였다. 마 음챙김은 현재 순간의 내외적 자극에 즉각적으로 반응하 거나 왜곡된 사고를 하지 않고 의식의 흐름과 상황, 감 정 등을 가능한 있는 그대로 관찰하는 주의집중 방식이 다[17]. 마음챙김기법이 임상적 처치나 현장의 문제를 해결하기 위해 활용될 때 사용되는 MBSR(Mindfulness Based Stress Reduction)의 기초를 제공하며 심리적, 신체적 장애극복과 개인의 성장과 발전에 긍정적인 효 과가 있는 것으로 알려져 있다[18]. 또한 긍정정서와 낙 관성, 행동조절 능력의 증가가 보고 되고 있으므로 심리 적, 신체적 손상을 입은 선수들에게 유용할 것으로 예 상되었다[19].

최근 스포츠심리학 연구에서 마음챙김과 최고 수행 사이의 관계가 정립되고 있으며[20], 상해 재활의 맥락 에서 마음챙김은 상해를 입은 선수들이 마음과 신체의 편안한 상태를 달성하고 상해 상황을 더 잘 이해하도록 하는데 유익한 것으로 보고되고 있다[21].

한편, 선행연구들은 부상선수들을 대상으로 한 연구 에서 회상적 방법의 이득과 유용성이 학문의 발전과 정 보제공 차원에서 장점이 있으나 한계가 동시에 존재함 을 지적하고 있다. 따라서 횡단적 연구나 연역적, 귀납 적 접근의 혼합방법의 필요성에 대해 강조해왔다. 본 연
구에서는 스포츠손상 후 재활훈련 중인 청소년 야구선 수의 마음챙김 기반 통증감소 및 재활심리 상담에 대해 사례를 보고하기 위해 양적 및 질적 방법의 혼합설계를 사용하였다. 이는 프로그램 처치의 결과를 다양한 관점 에서 해석을 가능케 하며 현장에서 선수들의 상담과 연 구에 있어 유용한 정보를 제공할 것으로 기대된다. 따 라서 본 연구의 목적은 스포츠 상해 후 운동 재활 중에 있는 야구선수를 대상으로 마음챙김 심리기술 프로그램 을 적용하고 그 변화를 관찰하는데 있다. 이를 통해 스 포츠 상해 선수들의 성공적인 재활과 복귀를 도와 이전 경기력의 회복을 돕고자 하며, 스포츠재활심리학의 기 초자료를 제공하는데 그 의의가 있다.

\section{연구방법}

본 연구의 프로그램 진행은 스포츠 상해 후 운동 재 활 중에 있는 청소년 야구선수들을대상으로 2018년 12 월 4 일부터 12 월 28 일까지 주 2회씩 4 주간, 총 8 회기 가 진행되었으며, 참여자 5 명 중 1 명은 개인적인 사정 으로 중도 포기하였다. 참여자들에게는 본 연구자가 고 안한 메뉴얼에 기초한 집단 프로그램을 진행하였으며, 이는 마음챙김 심리 기술 30 분, 워크시트 작성 50 분, 소 감나누기 30 분으로 총 1 시간 30 분에서 2 시간으로 구성 하였다. 구체적인 프로그램은 다음과 같다. 마음챙김 심 리기술 파트에서 자동조정 습관 알아차리기(호흡명상, 건포도 먹기명상, 바디스캔, 정좌명상)와 신체감각에서 정서인식하기(하타요가, 호흡과 심박수 세기), 스포츠심 리기술(스포츠상해와 목표설정, 신체이완법, 재활운동과 동기, 자신감훈련, 자기대화, 인지재구성, 심상, 재활 후 계획)에 이어 워크시트 및 나누기(일상의 자동조정 찾 아보기, 감사함 찾아보기, 오늘 어떤 경험을 하였는가? 등)를 실시하였다. 설문지는 프로그램 첫 회기 시작하 기 전과 마지막 회기가 끝난 후 총 2회 실시되었다. 본 연구진행자는 스포츠심리학 전공자로 스포츠심리 상담 사 1 급(한국스포츠심리학회), MBSR전문가 R급(한국명 상학회), 건강심리전문가(한국건강심리학회) 자격을 소 지하고 다수의 집단 프로그램에서 지도자로 활동한 경 력을 기반으로 연구자가 직접 프로그램을 진행하였다.

\section{측정 도구}

통증 감각에 대한 반응의 파국화 정도를 측정하고자 
한국판 통증 파국화 척도(Korean version of the Pain Catastrophizing Scale; K-PCS)를 사용하였다[22,23]. 점수가 높을수록 통증 감각에 대한 반응의 파국화 정도 가 높음을 의미하며, Cho 등(2013)의 연구에서 반추, 과장, 무력감, 전체 문항에 대한 Cronbach's 값은 각각 $.86, .71, .90, .93$ 으로 보고하고 있다. 마음챙김의 정도 를 측정하고자 한국판 개정 인지적 정서적 마음챙김 척 도(Korean Version of the Cognitive and Affective Mindfulness Scale-Revised; K-CAMS-R)척도를 사 용하였다[24,25]. 이는 점수가 높을수록 마음챙김의 수 준이 높음을 의미하며, 선행연구에서 알아차림, 주의, 수 용, 전체 문항에 대한 Cronbach's 값은 각각 .59, .75, $.44, .73$ 으로 보고하고 있다. 스포츠 선수들의 인지된 경기력을 측정하고자 인지적 경기력 척도를 사용하였 다[26,27]. 점수가 높을수록 인지된 경기력이 높음을 의미하며, 본 연구에서 전체 문항에 대한 Cronbach's 값은 .79로 나타났다.

운동선수의 심리기술과 심리 전략을 측정하고자 스 포츠 수행전략 척도(Test of Performance Strategies; TOPS)를 사용하였다 $[28,29]$. 점수가 높을수록 운동 수행전략이 뛰어남을 의미하며, 선행연구에서 혼잣말, 컨디션 조절, 심상과 목표설정, 긴장풀기, 감정 조절에 대한 Cronbach's 값은 각각 .82, .81, .76, .76, .67으 로 보고하고 있다[29]. 개인의 정서 상태를 측정하고자 정서상태 척도(Positive Affect and Negative Affect Scales; PANAS)를 사용하였다[30,31]. 점수가 높을 수록 각각 긍정 정서 및 부정 정서가 높음을 의미하며, 선행연구에서 긍정정서, 부정정서에 대한 Cronbach's 값은 각각 $.84, .87$ 로 보고하고 있다. 스포츠 상황 전에 느끼는 상태불안을 측정하고자 스포츠 경쟁불안 척도 (Competitive State Anxiety Inventory-2; CSAI-2)를 사용하였다[32,33]. 점수가 높고 자신감의 점수가 낮을 수록 불안이 높음을 의미하며, 선행연구에서 신체적 불 안, 인지적 불안, 자신감에 대한 Cronbach's 값은 각각 $.80, .75, .79$ 으로 보고하고 있다. 스포츠 활동과 관련하 여 개인이 심상 능력을 측정하고자 스포츠 심상능력 척 도(Sport Imagery Ability Questionnaire; SIAQ)를 사 용하였다[34,35]. 점수가 높을수록 심상 능력이 높음을 의미하며. 전략심상, 목표심상, 정서심상, 기술심상에 대 한 Cronbach's 값은 각각 .75, .79, .78, .74로 나타났다.

질적분석을 위하여, 4 가지 절차를 사용하였다[36].
이는 (1) 전체 진술에 대한 일반적인 인식을 얻기 위해 전 체 기술된 내용 읽기. (2) 의미 단위를 구별하려는 목적으 로 연구되는 현상에 초점을 맞추어 읽기. (3) “의미 단위” 의 윤곽이 파악되면 연구자가 모든 의미 단위를 검토하 고, 거기서 학문적 통찰을 좀 더 직접적으로 표현하기. (4) 변형된 모든 의미 단위를 연구 대상자의 경험에 관한 일 반적인 진술로 통합하기로 이루어져 있다.

\section{자료 분석}

본 연구의 양적 자료는 SPSS 23.0을 사용하여 분석 하였다. 수집된 자료는 연구대상자들의 인구통계학적 특 성을 알아보기 위해 빈도분석과 기술통계를 실시하였다. 또한 신뢰도 분석을 실시한 뒤, 프로그램 실시 후에 프 로그램의 개입효과를 검증하기 위해 개입 전과 개입 후 검사를 실시하여 대응표본 $\mathrm{t}$ 검증을 실시하였다. 질적 자료의 경우, 수집된 자료들을 토대로 전사(transcribe) 하여 부호화 과정을 통해 부호 체계를 작성하고 범주화 하여 주제를 분류하였다. 또한 질적 자료의 신뢰도와 타 당도를 확보하고자 삼각검증법(Triangulation)과 구성 원 간 검토(member check)를 실시하였다.

\section{증례}

참여자 $\mathrm{A}$ 는 17 세 남자로 초등학교 5학년부터 야구 를 시작하여 6 년의 경력을 가지고 있었다. 6 개월 전 팔 꿈치를 다쳐서 $\mathrm{OCD}$ 뼈 조각 제거 수술을 받았으며 재활 운동은 현재 주 6 시간, 1 일 3 시간씩 진행하고 있다고 하 였다. 야구 기술 훈련은 주 3 시간, 1 일 2시간씩 하고 있 었으며, 심리 기술 훈련을 받고 있는 것은 없었다. 약 8 개월 전부터 팔꿈치와 어깨에 통증이 시작되었으며, 특 히 재활 훈련할 때 통증이 심하여 스트레칭을 하고 있다 고 하였다. 심리적으로 가장 힘든 점은 야구를 해야 하 는데 하지 못하는 것이라고 보고하였다.

참여자 $\mathrm{A}$ 의 변화는 다음과 같다(Table 1).

참여자 $\mathrm{B}$ 는 17 세 남자로 초등학교 4 학년부터 야구 를 시작하여 6년 10 개월의 경력을 가지고 있었다. 14 개월 전 팔꿈치와 어깨를 다쳐서 인대 접합 수술을 받 았으며, 재활 운동은 현재 주 6시간, 1 일 4시간씩 8개 월째 하고 있다고 하였다. 야구 기술 훈련과 심리 기술 훈련을 받고 있는 것은 없었다. 약 14 개월 전부터 팔꿈 치와 어깨에 통증이 시작되었으며, 특히 재활 훈련할 때 통증이 심하여 재활 치료를 하고 있다고 하였다. 심리적 
Table 1. The Pre and Post Result of Participant A

\begin{tabular}{|c|c|c|c|c|c|c|c|c|}
\hline & Pain & Level of Pain & Mindfulness & Perceived Performance & Performance & Emotion & Competitive Anxiety & Imagery \\
\hline Pre & 2.46 & 6 & 1.75 & 2.38 & 2.42 & 2.10 & 3.22 & 3.50 \\
\hline Post & 0.38 & 4 & 3.33 & 4.13 & 4.13 & 3.70 & 1.96 & 5.85 \\
\hline Diff. & -2.08 & -2 & +1.58 & +1.75 & +1.71 & +1.6 & -1.26 & +2.35 \\
\hline
\end{tabular}

Table 2. The Pre and Post Result of Participant $B$

\begin{tabular}{lcccccccc}
\hline & Pain & Level of Pain & Mindfulness & Perceived Performance & Performance & Emotion & Competitive Anxiety & Imagery \\
\hline Pre & 3.85 & 6 & 2.17 & 3.25 & 3.04 & 2.20 & 3.11 & 3.65 \\
Post & 1.62 & 2 & 3.42 & 4.63 & 4.38 & 3.15 & 2.04 & 6.65 \\
Diff. & 2.23 & 4 & +1.25 & +1.38 & +1.34 & +0.95 & 1.07 & +3.00 \\
\hline
\end{tabular}

Table 3. The Pre and Post Result of Participant $C$

\begin{tabular}{|c|c|c|c|c|c|c|c|c|}
\hline & Pain & Level of Pain & Mindfulness & Perceived Performance & Performance & Emotion & Competitive Anxiety & Imagery \\
\hline Pre & 1.23 & 2 & 2.25 & 3.00 & 2.58 & 2.25 & 2.93 & 3.85 \\
\hline Post & 0.38 & 1 & 3.75 & 5.00 & 4.71 & 3.95 & 1.15 & 7.00 \\
\hline Diff. & 0.85 & 1 & +1.5 & +2.00 & +2.13 & +1.7 & 1.78 & +3.15 \\
\hline
\end{tabular}

Table 4. The Pre and Post Result of Participant $D$

\begin{tabular}{lcccccccc}
\hline & Pain & Level of Pain & Mindfulness & Perceived Performance & Performance & Emotion & Competitive Anxiety & Imagery \\
\hline Pre & 2.00 & 7 & 2.08 & 2.88 & 2.92 & 2.25 & 3.15 & 3.80 \\
Post & 0.23 & 3 & 3.42 & 5.00 & 4.67 & 3.95 & 1.26 & 6.75 \\
Diff. & 1.77 & 4 & +1.34 & +2.12 & +1.75 & +1.70 & 1.89 & +2.95 \\
\hline
\end{tabular}

으로 가장 힘든 것은 계속 팔이 아플까 봐 걱정되는 것 이라고 보고하였다.

참여자 $\mathrm{B}$ 의 변화는 다음과 같다(Table 2).

참여자 $\mathrm{C}$ 는 17 세 남자로 초등학교 5학년부터 야구 를 시작하여 5 년 3 개월의 경력을 가지고 있었다. 5 개월 전 팔꿈치를 다쳐서 팔꿈치수술을 받았으며, 재활 운동 은 현재 주 3 시간, 1 일 3 시간씩 5 개월째 하고 있다고 하 였다. 야구 기술 훈련과 심리 기술 훈련을 따로 받고 있 는 것은 없었다. 현재 팔꿈치에 통증은 없으나 심리적 으로 가장 힘든 것은 팔이 계속 아플까 봐 걱정되는 것 이라고 보고하였다.

참여자 C의 변화는 다음과 같다(Table 3).

참여자 $\mathrm{D}$ 는 15 세 남자로 초등학교 2학년부터 야구 를 시작하여 7 년의 경력을 가지고 있었다. 10 개월 전
팔꿈치를 다쳐서 팔꿈치수술을 받았으며, 재활 운동은 현재 주 6 시간, 1 일 3 시간씩 6 개월째 하고 있다고 하였 다. 야구 기술 훈련과 심리 기술 훈련을 따로 받고 있는 것은 없었다. 현재 통증은 없으나 심리적으로 가장 힘 든 것은 재활기간 동안 야구를 오랫동안 못하고 있어 서 실력이 늘지 않을까 걱정되는 것이라고 보고하였다.

$$
\text { 참여자 } \mathrm{D} \text { 의 변화는 다음과 같다(Table 4). }
$$

\section{결과}

\section{마음챙김 기반 심리기술 훈련 전 후 변화}

실험 집단에서 마음챙김 기반 심리기술 훈련 전 과 후에 변인의 차이가 있는지 검증하기 위해 Paired t-test를 실시하였다. 그 결과, 프로그램 실시 후에 통 
증 파국화 $(\mathrm{t}=-5.582, \mathrm{p}<.05)$, 마음챙김 $(\mathrm{t}=18.623$, $\mathrm{p}<.001)$, 인지된 경기력 $(\mathrm{t}=10.961, \mathrm{p}<.01)$, 스포츠 수 행전략 $(\mathrm{t}=10.686, \mathrm{p}<.01)$, 정서상태 $(\mathrm{t}=8.231, \mathrm{p}<.01)$, 스포츠 경쟁불안 $(\mathrm{t}=-7.597, \mathrm{p}<.01)$, 스포츠 심상능력 $(\mathrm{t}=16.261, \mathrm{p}<.01)$ 모두 효과가 유의한 것으로 나타났 다(Table 5).

\begin{tabular}{lccc}
\multicolumn{3}{l}{ Table 5. The Pre and Post Result of Measurement } \\
\cline { 1 - 3 } Independent Variables & Pre & Post & t \\
\cline { 2 - 3 } & $\mathbf{M}(\mathbf{S D})$ & $\mathbf{M}(\mathbf{S D})$ & \\
\hline Pain Catastrophizing & $2.38(1.10)$ & $0.65(0.65)$ & $-5.582^{*}$ \\
Mindfulness & $2.06(0.22)$ & $3.48(0.18)$ & $18.628^{* * *}$ \\
Previewed Performance & $2.88(0.37)$ & $4.69(0.41)$ & $10.961^{* *}$ \\
Performance Strategies & $2.74(0.29)$ & $4.47(0.27)$ & $10.686^{* *}$ \\
Emotional States & $2.20(0.07)$ & $3.69(0.38)$ & $8.231^{* *}$ \\
Competitive Anxiety & $3.10(0.13)$ & $1.60(0.46)$ & $-7.597^{* *}$ \\
Imagery & $3.70(0.16)$ & $6.56(0.50)$ & $16.261^{* *}$ \\
\hline${ }^{*} \mathrm{p}<.05,{ }^{* *} \mathrm{p}<.01,{ }^{* * *} \mathrm{p}<.001$ & & & \\
\end{tabular}

\section{질적 분석}

1) 마음챙김

이 영역은 마음챙김 측정 도구와 같이 알아차림, 주 의, 수용으로 범주화 되었다. 참여자들은 프로그램에 참 여하면서, 먼저 이전 경험에 대한 알아차림을 하기 시작 했는데, 진술은 다음과 같다.

“항상 공을 던지고 나면 아이스를 하고 $\cdots$ 의식없이 해 버렸어요."〈참여자 $\mathrm{B}$ >

"재활훈련 할 때 하다 보면 맥없이 하고 있는 걸 느꼈 어요."〈참여자 A>

프로그램 후반엔 주의와 수용을 보고하기도 하였으 며, 진술은 다음과 같다.

“저는 제 앞 친구한테 잠깐 주의를 뺏겼지만 다시 돌아 오려고 노력했어요."〈참여자 B>

"(중략) 그리고 저는 부상으로 수술을 했지만 이제는 다르게 생각하려구요."〈참여자 A>

\section{2) 스포츠 심상}

프로그램을 진행하며 참여자들은 운동과 관련한 심 상을 접했으며 목표 심상과 기술 심상에 대해 보고하 였다. 참여자의 목표 심상에 대한 진술은 다음과 같다.
"1단계 기억에 남는 사람. 예쁜 여자한테 인기 많은 사 람. 2 단계 야구 선수로서 한 발자국 다가가기. 3단계 타자 4할 이상. 키 많이 크기”〈참여자 A>

“ 1 단계 야구 선수 등 성공해서 부와 명예를 얻기. 2 단 계 몸 안 아프고 부상 없이 한 해 마무리하기. 2학년 때 4 할 이상 치기. 3 단계 웨이트 꾸준히 하면서 재활도 같 이 하기. 야구 외에 무리한 운동이나 일 하지 않기. 스 윙 기술들을 완성시킨다. 대기 타석에서 투수 볼을 연 구하고 타이밍을 맞춘다."〈참여자 B>

“명예로운 인간. '참여자 C 이름' 하면 딱 나인 줄 아 는 사람. 인성 좋은 사람. 초록 검색 창에 먼저 뜨는 사 람"〈참여자 C>

"야구 선수로 성공해서 부와 명예를 가진 사람. 성실한 사람. 홈런 5 개 이상 치기. 내가 하는 수비 위치에서 핫 되기. 기술 운동 하루에 2 시간 이상 하기. 웨이트, 하 체 운동 등 꾸준히 하기. 하루에 달리기 30 분 이상 하 기”<참여자 D>

또한 참여자들이 보고한 기술 심상은 다음과 같다. "타석에 들어섰을 때나 수비했을 때 모자를 꽉 조이게 쓰구요. 투수할 땐 헐렁헐렁하게 쓰고 그리고 세트 포지 션 때는 왼 다리를 피고 오른 다리를 구부리고, 바깥쪽을 던질 때는 바깥으로 다리 빼고 몸 쪽 던질 때는 몸 쪽으 로 다리 빼고 호흡하고 던집니다."〈참여자 A>

"그리고 타석에서 이제 들어가서 앞 선 타자가 친 땅을 고르고 땅을 골라 준 다음에 제 오른쪽 발이 고정되게 땅을 파주고 투수를 보면서 생각을 합니다. 구종이 뭔 지 $\cdots$ 최고 구속은 몇 키로 인지 $\cdots$ 대충 생각을 하고 이 제 심호흡을 하면서 집중을 조이고 방망이와 어깨를 탁 탁 털면서 힘을 빼고..."<참여자 B>

\section{3)심리적 안정}

참여자들은 프로그램을 통해 심리적인 안정감을 여 러차례 보고하였다. 주로 명상을 하고 난 뒤 안정감을 보고하였는데, 이에 대한 진술은 다음과 같다.

"마음이 좀 더 좋아진 것 같고 평화로워진 것 같아

요."〈참여자 A>

“(중략) 호흡하니까 편안해 졌어요."〈참여자 B> “호흡 명상 끝나고 나니까 마음이 고요해 진 것 같아 요."〈참여자 C> 
“호흡 명상 때 살짝 졸았어요. 근데 지금 굉장히 정신 이 맑아진 것 같아요. 잠이 확 깬 것처럼" “명상할 때 마음이 참 편했어요."〈참여자 D>

\section{4) 치료 효과}

본 프로그램을 통해 참여자들이 보고한 치료적 효과 는 다음과 같다.

“(중략) 제가 여태까지 중학교에서 해왔던 안 좋은 부정 적인 생각들 $\cdots$ 여기 와서 다시 생각하게 되었고. 복귀가 얼마 안 남았지만 복귀에 대한 걱정이 제일 컸는데 이제 좀 덜 생각하게 되었습니다."<참여자 B>

“제가 생각했던 게 좀 잘못되었다는 것을 알게 되었고 $\cdots$ (중략) 이제 재활하면서 마음도 아프고 상하고 그랬지만 그래도 이제 기분 좋게 재활하면서 앞날을 창창하게 밝 게 해 줄 저의 믿음을 생각했습니다.(중략) 그리고 이제 제가 명상을 왜 하는지 잘 몰랐었는데 명상을 한다는 게 정말 좋다는 걸 알게 되었어요."〈참여자 C>

“심호흡이 마음을 진정시키는데 도움이 많이 되는지도 처음 알았고, 루틴이 행동인 줄 알았는데 이런 신경도 다 느끼면서 하는지 처음 알았어요. 명상이 도움이 되 는 것도 알았고요. 내년 시즌 되어서도 긍정적인 말 많 이. 부정적인 말보다 긍정적인 말 많이 해야겠고.." <참 여자 D>

\section{논의}

오랫동안 지도자, 운동선수 재활 전문가, 의료계 종 사자들은 부상선수들을 우선적으로 신체적인 평가에 초 점을 맞춰 복귀 시켜 왔으며[37], 대부분의 부상 선수 는 부상 이전의 건강과 수행 수준으로 완전히 회복하기 도 하지만, 많은 선수들이 부상 이전의 수준으로 회복 하는데 실패를 경험하기도 한다[2], 이러한 실패의 원 인은 많은 경우 심리적 원인일 수 있다. 즉 심리적 요인 은 부상 발생에 영향을 미칠 수 있고 또한 선수들이 부 상에 성공적으로 대처하고 나아가 재활의 성공에 영향 을 미칠 수 있다[3]. 실제 스포츠 손상은 자신감 감소, 개인 정체성 상실, 불안, 우울, 고립감 등과 관련이 있 는 것으로 밝혀졌다[9]. 즉 선수들이 육체적으로 치료 되고 재활되었더라도 정신적으로는 스포츠 경쟁에 참여 하기 위한 준비가 되어 있지 않을 수 있다[38]. 많은 경 험적, 학문적 사례들이 제시하 듯 재활에서 훈련과 경
기로 성공적인 복귀를 하는 것은 부상선수들에게 쉽지 않은 일이다[39]. 그럼에도 불구하고 오랫동안 부상선 수들의 복귀에 있어 심리적인 처치는 간과되어 왔는데, 스포츠심리학자의 지식들을 통해 선수들의 성공적인 복 귀에 도움을 줄 수 있을 것이라는 확신을 가지고 본 연 구가 시작되었다.

본 연구에서는 주로 팔꿈치에 스포츠손상을 입고 재 활운동에 참여하고 있는 야구 주니어 선수 4 명(중2-고 1)을 대상으로 마음챙김 심리기술을 적용하여 그 변화 를 관찰하고 선수들의 성공적인 재활과 복귀를 도와 경 기력을 회복시키고 특히 스포츠손상에 있어 신체적인 재활뿐만 아니라 심리적인 재활의 중요성을 조명하고 자 하였다. 연구결과를 보면 총 8회기의 본 연구에 참 여한 선수들에게서 마음챙김 기반 심리기술 훈련 전과 후에 차이가 있는 것으로 나타났다. 프로그램 실시 후 에 통증 파국화 $(\mathrm{t}=-5.582, \mathrm{p}<.05)$, 마음챙김 $(\mathrm{t}=18.623$, $\mathrm{p}<.001)$, 인지된 경기력 $(\mathrm{t}=10.961, \mathrm{p}<.01)$, 스포츠 수 행전략 $(\mathrm{t}=10.686, \mathrm{p}<.01)$, 정서상태 $(\mathrm{t}=8.231, \mathrm{p}<.01)$, 스포츠 경쟁불안 $(\mathrm{t}=-7.597, \mathrm{p}<.01)$, 스포츠 심상능력 $(\mathrm{t}=16.261, \mathrm{p}<.01)$ 모두에서 유의한 효과가 있는 것으로 나타났다. 양적연구에서 처럼 질적분석에서도 마음챙김, 심상, 심리적 안정, 치료효과가 있는 것으로 나타났다.

선행연구가 많지는 않으나 재활 맥락과 회복과정에 서 심상화의 치유효과와 이점에 대한 실험 연구결과, 재 활과정동안 더 빠르게 회복한 선수들은 회복속도가 느 린 선수들보다 치유심상화를 훨씬 더 많이 사용했으며, 창의적인 시각화를 통해 치료에 대한 자신의 책임감을 가지려는 경향이 있었던 것으로 보고되고 있다[40,41]. 신체적 재활과 더불어 치유 심상화 혹은 이완프로그램 을 병행했을 때 무릎 스트레칭의 증가, 재 부상에 대한 불안감이나 통증의 감소에 효과가 있는 것으로 나타났 다[40].

지금까지 재활과정에 통합된 심상화에 대한 이론적 체계는 없으나 잘 알려진 스포츠심상화 모델(Applied Model of Imagery Use in Sport,AMIUS)은 심상화 유 형이 중심이 되며, 심상화는 인지적이고 효과적이며 행 동적 성과의 결정 요인으로 작용한다고 본다[42]. 또한 스포츠손상 재활과정에 스포츠심상회 모델(AMIUS)을 적용할 때 심상화유형은 신체적 치유과정을 원활하게 하고, 선수들의 통증 대처를 도우며 재활의 동기부여를 높이고, 스포츠 특화 기술 및 전략을 유지시키며, 재활 
의 준수와 지속, 스포츠현장 복귀를 위한 심리적 준비 와 신체적 전략을 지원하는 것으로 보고되고 있다[1].

운동선수들은 재 부상에 대한 걱정, 부상 전과 같이 수행하지 못할 것에 대한 두려움, 주변인들과 지도자의 기대에 부흥하지 못할 것이라는 생각을 갖고 있는 것으 로 알려져 있다. 또한 운동선수들이 명확한 날짜에 복 귀해야 한다는 압력에 직면하게 될 것이라고 주장한다 [39]. 부상 선수들은 엘리트 선수 집단에서 자신들의 동료애를 잃을 것을 두려워하거나 외부 압력에 의해 재 활이 완료되지 않은 시점에 복귀 할지도 모른다는 걱정 을 하는 경유도 종종 있다. 많은 부상선수들은 팀 동료 와 코치들, 개인그룹으로부터 외로움과 소외감을 갖고 있기 때문이다. 이러한 실례들은 운동선수들이 재활 후 복귀 이전이나 재활과정 중 심리적인 어려움을 경험한 다는 것을 의미한다[39]. 특별한 경우에는 스포츠에 돌 아갔을 때 스트레스 원천으로 부정적 사회비교로 인해 정체성의 문제를 겪거나 운동선수들은 높은 수행의 예 상과 실망의 결과로 자신감을 상실할 수도 있다. 이러한 문제를 방지하고 해결하고자 본 연구에서는 심리적 재 활을 실행하고 그 변화를 관찰하였다[38].

본 연구에서는 통증 파국화와 다양한 정서적, 수행요 인에 있어 심리재활의 긍정적 효과를 발견하였다. 통증 은 골절과 같은 생물학적 원인에 의해 발생되기도 하며 이를 진단하고 치료하는 것은 당연하다. 진통제 복용이 나 여러 가지 의학적 처치에 의해 통증의 원인을 제거 하고 치료할 수 있다. 하지만 통증치료가 여기에서 끝난 다면 이후의 통증 반응이나 통증 경험은 통제되기 어렵 다. 이유는 통증에 대한 인지적, 정서적 반응은 독특한 개인의 주관성이 반영되며, 이후 수행 저하를 야기할 수 있는 통증 경험에 영향을 미칠 수 있기 때문이다[43].

인지적, 정서적 요인들이 부상 그 자체 보다 통증 경 험을 더욱 잘 이해하게 할 수 있다고 알려져 있다[44]. 피로, 불편함, 긍정적 훈련 통증은 재활 기간에 있어 필 연적이며 발전에 대한 긍정적인 신호로 해석될 수 있다. 그러나 이러한 통증들이 부정적으로 받아들여졌을 때는 선수들의 재활중단이나 스트레스의 원인이 될 수 있다. 또한 우울과 불안은 각성 증가와 긍정적인 대처행동을 방해함에 따라 통증인식을 높인다. 본 연구에서는 선수 들이 마음챙김 기반 통증감소 및 재활심리 상담에 참여함 으로써 통증 인식이 개선됨을 확인 할 수 있었다.

통증 파국화는 통증감각에 지나친 집중으로 인한 사
고 과정으로 위협의 과해석과 이를 대처하지 못할 것이 라는 인식을 동반한다. 이러한 파국화는 통증경험을 증 가시키고 스트레스를 야기하는 것으로 알려져 있다. 통 증파국화 반응은 불안, 근 긴장, 통증강도를 증가시킨 다. 따라서 본 연구에서 마음챙김을 통해 본인에게 무 엇이 일어나는지 있는 그대로 알아차리고 즉각 반응하 지 않고 탈 중심적 태도를 가질 수 있었던 것이 긍정적 효과를 얻은 이유라고 사료된다.

두 번째로 본 연구에서는 재활중인 운동선수들의 운 동선수로서 심리기술향상과 심리적 재활의 효과를 규명 하였다. 그 결과 다양한 심리요인의 개선을 확인할 수 있었다. 부상이나 정신적인 충격은 지속적으로 교감신 경계의 각성상태를 유발하며 [45], 수면 장애 및 정서적 마비, 해리증상의 경우 역시 과각성을 동반한다[46]. 따 라서 심리 재활 과정 중 불안 등의 개선 결과는 과각성 과 같이 교감신경계의 각성 증상들을 감소시키는데 영 향을 미친 것으로 판단된다. 이 같은 결과에 영향을 미친 논리에 대해 선행연구에서는 마음챙김 기법이 스포츠에 서 심리기술과의 증진 효과에 대해 논의하였다 $[47,48]$. 즉, 마음챙김 기법에서 강조하는 가치의 명확성이 동기 와 목표에 긍정적 영향을 미치며, 자기조절은 대처전략, 각성, 의사소통, 리더십 등에 도움이 될 것으로 보았다. 또한 직면하고 있는 문제와의 능동적 노출(exposure) 은 의지향상과 통증관리에 잠재적 영향을 줄 것으로 예 상하였다[47]. 따라서 이러한 마음챙김 기법의 적용은 재활 중인 선수들의 심리기술에 긍정적인 영향을 미친 것으로 사료된다.

마음챙김 기법과 스포츠 수행과 관련된 선행연구에 서는 마음챙김의 효과는 집중과 주의력 향상, 감정조절, 몰입과 최고수행과 관련된 최적기능상태의 향상에 긍정 적 영향을 미친다고 주장하였다[49]. 마음챙김의 현재 에 머무는 것과 수용, 탈중심화와 같은 주요요소는 수 영, 양궁, 골프, 조정, 육상 등 다양한 개인 및 단체 종목 에서 수행향상의 효과가 입증되고 있다 [50-53]. 또한 마음챙김 기법을 운동선수들에게 적용함으로써 내-외 조기술 및 개방-폐쇄 기술 종목에서 몰입경험과 주의 력이 향상되는 효과를 보고한 연구들도 있다 $[54,55]$.

또한 십자인대 상해로 인한 재활 운동선수의 경험을 탐구하고 마음챙김을 개입한 연구에서는 마음챙김이 좌 절감, 지루함, 불안 등과 같은 감정을 수용하는데 유용 하였으며, 이는 선수들의 안녕과 재활 중 행동발달에 도 
움을 줄 수 있는 것으로 나타났다[21].

본 연구에서는 스포츠 손상선수에게 마음챙김을 기 반으로 하되, 목표설정, 자신감 및 이완훈련(센터링과 횡 격막호흡, $4: 7: 8$ 호흡), 자기대화, 심상 및 루틴 훈련 등 의 심리기술이 적용되었다. 이러한 프로그램을 구성하 게 된 근거는 스포츠상해 선수의 재활과정에 목표설정, 심상화, 자기대화 그리고 이완기법을 적절하게 심리기 법 훈련 패기지에 통합할 때 실제 상호보완적인 효과가 있다고 한 보고에 기인하였다[3]. 특히 스포츠상해 선 수의 재활과정에 이완기법은 필수적 요소이므로 본 연 구에서는 심신의 이완목적으로 마음챙김의 호흡명상 외 에 센터링과 횡격막 호흡, $4: 7: 8$ 호흡을 적용하다. 그 근 거는 호흡조절기법은 교감신경과 부교감신경의 연결로 느린 호흡이 스트레스 보조 성질을 갖고있어 불안 및 근 육 긴장 스트레스를 조절하는 방법 중 가장 쉽고 효과적 인 방법이라고 한 선행 보고에 있다[56].

본 연구의 질적분석 결과, 마음챙김, 심상, 심리적 안 정, 치료효과가 나타나 양적 결과에 추가적인 효과를 확 인 할 수 있다, 이는 마음챙김에의 집중은 재활 운동에 정확히 집중할 수 있도록 하며, 신체적 개입으로부터 얻 은 이익을 최대화 할 수 있도록 한다는 선행연구 보고를 지지하는 것이다[21].

따라서 본 연구의 결과는 재활선수들의 심리적인 문 제들을 해결하는 심리재활의 중재는 정서적, 행동적, 인 지적 문제들을 해결하고 향후 복귀 시 수행에 있어 도움 이 될 수 있음을 발견하였다. 재활 중에는 신체적인 훈 련이 제한적이기 때문에 불안조절, 심상, 대처전략 등 심리기술을 배양할 수 있는 시간으로 활용될 수 있다. 이 같은 중재는 신체적인 활동과 훈련이 제한적인 것을 보완하여 오히려 재활기간 동안 새로운 관점을 획득하 고 심리적 기술을 배양할 수 있는 새로운 기회를 제공할 것이다. 본 연구를 시작으로 다양한 종목 군과 부상 유 형에 따라 선수들을 구분하여 신체적 재활뿐만 아니라 심리적 재활의 중요성이 활발히 논의되기를 기대한다.

\section{결론}

본 연구는 스포츠손상을 입고 재활 운동에 참여하고 있는 청소년 야구선수 4명(중2-고1)을 대상으로 마음 챙김 심리기술을 4주간 총 8회기를 적용하여 그 변화를 관찰하는데 목적이 있다. 그 결과 통증 파국화, 마음챙
김, 인지된 경기력, 스포츠수행전략, 정서상태, 스포츠 경쟁불안, 스포츠심상능력에 변화가 있었다. 또한 질적 분석을 통해 마음챙김, 심상, 심리적 안정, 치료효과가 나타나 양적 분석을 통해 나타난 결과 외에 추가적인 효과를 확인 할 수 있었다. 즉 마음챙김 기반 프로그램의 적용은 참여자들로 하여금 통증 인식의 개선과 심리기술 의 증진을 경험하게 하였다. 이 같은 중재 프로그램은 운 동선수들로 하여금 재활 기간 중 격을 수 있는 심리적 문 제를 해결하고 재활에 집중을 도모하며 재 부상에 대한 불 안을 낮춰 스포츠현장에의 복귀 후에도 이전 경기력을 회 복하는데 도움을 줄 수 있을 것으로 사료된다.

스포츠 상해는 선수가 직면한 상해 정도나 형태 등에 따라 다양할 것이다. 이에 향후 스포츠 상해 선수의 신체 재활과정에 적용될 다양한 심리적 중재기법 개발과 프로 그램의 효과성 검증, 그 외 신체에 대한 트라우마 중재기 법의 개발이 절실하다. 본 연구가 진행되는 시점에 동일 한 상해 부위의 비교 선수를 선정하지 못한 한계점이 있 다. 스포츠손상 재활 선수에 대한 연구에서 가장 난제이 긴 하지만, 향후 연구에서는 동일 조건의 비교집단을 배 치할 필요가 있다. 또한 상해 후에 대한 심리재활의 처치 뿐 아니라 상해 전의 생리-심리-사회적 요인들에 대한 연 구의 활성화와 현실적 적용으로 스포츠선수의 상해를 예 방하는 것 또한 중요하다고 사료된다.

\section{Acknowledgments}

이 논문은 2017년도 성신여자대학교 학술연구조성 비 지원에 의하여 연구되었음

\section{Conflicts of Interest}

The authors declare no conflict of interest.

\section{References}

1. Walker N, Arvinen-Barrow M. Introduction to the psychology of sport injuries. The Psychology of Sport Injury and Rehabilitation 2013, p 22-25.

2. Taylor J, Taylor S. Psychological approaches to sports injury rehabilitation. Lippincott Williams \& Wilkins. 1997.

3. Arvinen-Barrow M, Hemmings B, Weigand D, Becker C, Booth, L. Views of chartered physiotherapists on the 
psychological content of their practice: a follow-up survey in the UK. Journal of Sport Rehabilitation. 2007; 16(2):111-121.

4. Clement D, Granquist, M, Arvinen-Barrow, M. Psychosocial aspects of athletic injuries as perceived by athletic trainers. Journal of Athletic Training. 2013; 48(4):512521.

5. Heaney C. Physiotherapists' perceptions of sport psychology intervention in professional soccer. International Journal of Sport and Exercise Psychology. 2006; 4(1):7386.

6. Hemmings B, Povey L. Views of chartered physiotherapists on the psychological content of their practice: a preliminary study in the United Kingdom. British Journal of Sports Medicine. 2002; 36(1):61-64.

7. Larson G, Starkey C, Zaichkowsky L. Psychological aspects of athletic injuries as perceived by athletic trainers. The Sport Psychologist. 1996; 10(1):37-47.

8. Walker $\mathrm{N}$. The meaning of sports injury and re-injury anxiety assessment and intervention. Doctoral dissertation, Aberystwyth University. 2006.

9. Leddy M, Lambert M, Ogles B. Psychological consequences of athletic injury among high-level competitors. Research quarterly for exercise and sport. 1994; 65(4):347-354.

10. Petitpas A, Danish S. Caring for injured athletes. S. Murphy (Ed.), Sport psychology interventions. Champaign, IL: Human Kinetics. 1995, p 255-281.

11. Wiese-Bjornstal D, Smith A. LaMott, E. A model of psychologic response to athletic injury and rehabilitation. Athletic training: sports health care perspectives. $1995 ; 1(1)$ : 17-30.

12. Heil J. (2000). The injured athlete. Y. Hanin (Ed.) Emotions in sport. Champaign, IL: Human Kinetics. 2000, p 245 -265 .

13. Taylor J. Wilson G. Applying sport psychology: four perspectives. Human Kinetics. 2005.

14. LaMott, E. The anterior cruciare ligament injured athlete: The psychological process. Unpublished doctoral dissertation. University of Minnesota, Minneapolis. 1994.
15. Morrey, M. A. A longitudinal examination of emotional response, cognitive coping, and physical recovery among athletes undergoing anterior cruciate ligament reconstructive surgery. Unpublished dissertation, University of Minnesota, Minneapolis. 1997.

16. Sullivan M, Stanish W, Waite H, Sullivan M, Tripp D. Catastrophizing, pain, and disability in patients with soft-tissue injuries. Pain. 1998; 77(3):253-260.

17. Kabat-Zinn, J. (2003). Mindfulness-based interventions in context: past, present, and future. Clinical psychology: Science and practice. 2003; 10(2):144-156.

18. Brown K, Ryan R, Creswell J. Mindfulness: Theoretical foundations and evidence for its salutary effects. Psychological inquiry. 2007; 18(4):211-237.

19. Schonert-Reichl K, Lawlor M. The effects of a mindfulness-based education program on pre-and early adolescents' well-being and social and emotional competence. Mindfulness. 2010; 1(3):137-151.

20. Kee Y, Wang C. Relationships between mindfulness, flow dispositions and mental skills adoption: A cluster analytic approach. Psychology of Sport and Exercise. 2008; 9(4):393-411.

21. Mahoney J. Harahan S. A brief educational intervention using acceptance and commitment therapy: Four injured athletes' experiences. Journal of Clinical sport psychology, 2011; 5:252-273.

22. Sullivan M, Bishop S, Pivik J. (1995). The pain catastrophizing scale: development and validation. Psychological assessment. 1995; 7(4):524-532 23. Cho S, Kim H-Y, Lee J-H. Validation of the Korean version of the Pain Catastrophizing Scale in patients with chronic non-cancer pain. Quality of Life Research, 2013; 22(7):1767-1772.

24. Feldman G, Hayes A, Kumar S, Greeson J, Laurenceau, J. Mindfulness and emotion regulation: The development and initial validation of the Cognitive and Affective Mindfulness ScaleRevised (CAMS-R). Journal of Psychopathology and Behavioral Assessment. 2007; 29(3):177-190. 25. Cho Y. The reliability and validity of a Korean version of the cognitive and affective mindfulness scale- 
revised. The Korean Journal of Clinical Psychology. 2009; 28(3):667-693.

26. Mamassis G, Doganis G. The effects of a mental training program on juniors pre-competitive anxiety, selfconfidence, and tennis performance. Journal of Applied Sport Psychology. 2004; 16(2):118-137.

27. Kang G, Kim S-H, Kwon S-M, Lee H-W. The effects of tae kwon do athletes' self-management on their cognitive performance. The Journal of Korean Alliance of Martial Arts. 2009; 11(2):205-219.

28. Thomas P, Murphy S, Hardy L. Test of performance strategies: Development and preliminary validation of a comprehensive measure of athletes' psychological skills. Journal of Sports Sciences. 1999; 17(9):697-711. 29. Kim B-J, Oh S-H. Preliminary validation of the Korean version of the test of performance strategies (tops): item development and factor structure. The Korean Journal of Measurement and Evaluation in Physical Education and Sport Science. 2002; 4(1):13-29.

30. Watson D, Clark L, Tellegen A. Development and validation of brief measures of positive and negative affect: the PANAS scales. Journal of Personality and Social Psychology. 1988; 54(6):1063-1070.

31. Lee H-H, Kim E-J, Lee M-K. A Validation Study of Korea Positive and Negative Affect Schedule: The PANAS Scales. Korean Journal of Clinical Psychology. 2003; 22(4):935-946.

32. Martens R, Burton D, Vealey R, Bump L, Smith D. Development and validation of the competitive state anxiety inventory-2. Competitive anxiety in sport. 1990, p 117-190.

33. Hong S-H, Woo M-J. Correlational Analysis of Competitive Anxiety and Frontal EEG Asymmetry Score. Korean Journal of Sport Psychology, 2013; 24(2):1-13

34. Williams S, Cumming J. Measuring athlete imagery ability: The sport imagery ability questionnaire. Journal of Sport and Exercise Psychology. 2011; 33(3):416-440. 35. Yang S-J. Experiences and perception on imagery use of elite athletes in modern pentathlon. Korea National Sport University. 2013.
36. Giorgi A. Phenomenology and psychological research. Pittsburgh: Duquesne University Press. 1985

37. Gould D, Bridges D, Udry E, Beck L. Stress sources encountered when rehabilitating from season-ending ski injuries. The Sport Psychologist. 1997; 11(4):361378.

38. Podlog L. Eklund R. Assisting injured athletes with the return to sport transition. Clinical Journal of Sport Medicine, 2004; 14:257-259.

39. Bianco T. Social support and recovery from sport injury: Elite skiers share their experiences. Research quarterly for exercise and sport. 2001; 72(4):376-388.

40. Cupal D. Brewer B. Effects of relaxation and guided imagery on knee strength, re-injury anxiety, and pain following anterior cruciate ligament reconstruction. Rehabilitation Psychology. 2001; 46(1):28-43.

41. Handegard L, Joyner A, Burke K, Reimann B. Relaxation and guided imagery in the sport rehabilitation context. Journal of Excellence, 2006; 11:146-164.

42. Martin K, Moritz S, Hall C. Imagery use of in sport: A literature review and applied model. The Sport Psychologist. 1999; 13:245-268.

43. Sullivan M, Stanish W, Waite H, Sullivan M, Tripp D, Catastrophizing, pain, and disability in patients with soft-tissue injuries. Pain. 1998; 77(3):253-260.

44. Turner J, Jensen M, Warms C, Cardenas D. Catastrophizing is associated with pain intensity, psychological distress, and pain-related disability among individuals with chronic pain after spinal cord injury. Pain. 2002; 98(12):127-134.

45. Butcher J, Mineka S, Hooley J, Klinische Psychologie (13., akt. Auflage). München: Pearson Studium. 2009.

46. Sterlini G, Bryant R. Hyperarousal and dissociation: A study of novice skydivers. Behaviour Research and Therapy. 2002; 40(4):431-437.

47. Yook Y-S. The effect of the mindfulness-based psychological skills training (MBPST) on Gymnasts. Korean Journal of Sport Psychology. 2017; 28(3):35-49.

48. Birrer D, Röthlin P, Morgan G. Mindfulness to enhance athletic performance: Theoretical considerations and possible impact mechanisms. Mindfulness. 
2012; 3(3):235-246

49. Jekauc D, Kittler C, Schlagheck M. Effectiveness of a mindfulness-based intervention for athletes. Psychology. 2017; 8:1-13.

50. Bernier M, Thienot E, Codron R, Fournier J. Mindfulness and acceptance approaches in sport performance. Journal of Clinical Sport Psychology. 2009; 3(4):320333.

51. Kaufman K, Glass C, Arnkoff D. Evaluation of Mindful Sport Performance Enhancement (MSPE): A new approach to promote flow in athletes. Journal of Clinical Sport Psychology. 2009; 3(4):334-356.

52. Pineau, T, Glass C, Kaufman K, Bernal D. Self-and team-efficacy beliefs of rowers and their relation to mindfulness and flow. Journal of Clinical Sport
Psychology. 2014; 8(2):142-158.

53. Pineau T. Effects of mindful sport performance enhancement (MSPE) on running performance and body image: does self-compassion make a difference. Unpublished Doctoral Dissertation, Washington DC: The Catholic University of America. 2013.

54. Aherne C, Moran A, Lonsdale C. The effect of mindfulness training on athletes' flow: An initial investigation. The Sport Psychologist, 2011; 25(2):177-189.

55. Chiesa A, Calati R, Serretti A. Does mindfulness training improve cognitive abilities? A systematic review of neuropsychological findings. Clinical psychology review, 2011; 31(3):449-464.

56. Weinberg R, Gould D. Foundations of Sport and Exercise Psychology. Champaign, IL: Human Kinetics. 2011. 